2021, Volume 16, ATEE 2020 - Winter Conference. Teacher Education for Promoting WellBeing in School. Suceava, 2020, pages: 163-171|

https://doi.org/10.18662/lumproc/atee2020/12

\section{Evaluation of Learning in the Period of Early Education}

\section{Ileana Constanţa DÂRLĂ (IONESCU) ${ }^{1}$}

1 Ph.D University of Bucharest, Psychologies and Educational Science Faculty ionescuile@gmail.com

\begin{abstract}
At all levels of education, learning assessment is generally considered to be an essential part of teachers' work. For early childhood educators, ie those who work with children from birth to age six, there are special considerations that stem from the characteristics of those trained and the nature of early learning. This paper reviews research on the formative assessment of early learning and development. In this way, important theoretical constructs related to early learning are explored and research on key aspects of early childhood learning is synthesized. We discuss the methods that are most useful for painting a richer picture of early learning and development. Some of the challenges inherent in formative assessment in early childhood are also bighlighted and discussed.
\end{abstract}

Keywords: formative evaluation; early childhood and development; professional knowledge; ethics

How to cite: Dârlă (Ionescu), I. C. (2021). Evaluation of Learning in the Period of Early Education. In O. Clipa (vol. ed.), Lumen Proceedings: Vol. 16. ATEE 2020 - Winter Conference. Teacher Education for Promoting Well-Being in School. Suceava, 2020 (pp. 163-171). Iasi, Romania: LUMEN Publishing House. https://doi.org/10.18662/lumproc/atee2020/12 


\section{Introduction}

At all levels of the education system, assessment is becoming increasingly important in the opinion of educators about their work with children, but also about their responsibility to society. In addition, the principle that assessment influences teaching and teaching involves assessment is considered as important in early education as it is in other levels of the education system (Bowman et al., 2001; Clipa \& Mata, 2020; Shepard et al., 1998).

There is a long tradition of observing the child in early education. Many of the pioneers in the field (eg, Froebel, Piaget, Vygotsky, and Issacs) strongly promoted the processes of observing, listening, and reflecting on children's actions and words. There have been significant theoretical developments in recent decades in the way we think about early learning (and development). The most important theorists (Anning et al., 2009) have documented and described the significance and challenges of theories. sociocultural aspects of all aspects of practice, including assessment. Traditional approaches, as well as recent advances in both theory and practice, together provide the foundation for contemporary approaches to evaluation.

Both between and within countries, the heterogeneity that characterizes early education gives rise to differences in curriculum approach, in terms of teaching and, consequently, in terms of assessment. In Ireland, as elsewhere, early education takes place in a variety of places, including nurseries, kindergartens, primary schools and family care centers. This leads to considerable diversity in terms of access, funding, training and child-adult relationships and also undoubtedly leads to considerable variations in quality from one context to another. In Ireland, the new national framework open framework for early education, The Framework for Early Learning can help to create a certain homogeneity in the quality of children's learning experiences from birth to six years. The interrelationship between curriculum and assessment means that early learning assessment issues and considerations are now being addressed in Ireland in an imperative manner and in a way that promotes coherence between curriculum and learning assessment. the curriculum tries to promote it. 
Indeed, there must be a constant interaction between curriculum and assessment "to ensure the effectiveness of one" (Blenkin \& Kelly, 1996). In recognition of this interaction, the NCCA will issue guidance on assessing early learning, which should accompany the curriculum when it is published.

This paper seeks to bring together key issues and considerations related to day-to-day assessment in the various settings in which early education is conducted. Taking them into account can help to theorize, establish and model / reshape assessment practices, especially in countries such as Ireland, where common structures, curricula and values are still developing. At a practical level, this paper describes some of the most important methods and approaches used in the formative assessment of early learning.

A number of interesting problems, tensions and challenges that arise in the material are explored, highlighted and discussed.

\section{A definition of formative assessment}

In the US, Bowman et al. (2001) suggest that the term assessment, as applied in early childhood education, generally implies the intention to provide a rich picture of how young children act, think, and learn. When the educator makes judgments to support children in learning based on information obtained through observation and interaction with them, then assessment is considered formative, i.e. it promotes learning (Gipps 1994; Torrance, 2001). A recent large-scale longitudinal study of early education in England confirmed the importance of formative assessment in meeting children's needs and supporting them in learning. It is argued that the assessment should be in support of young children:

"We can use our assessments to shape and enrich our curriculum, our interactions, as a whole: we can use our assessments as a way to identify what children will be able to learn in the future, so that we can support and expand this learning. Evaluation does part of our daily practice in trying to achieve quality" (Drummond, 1993, p. 13).

Thus, the paper focuses on identifying and promoting approaches 
formative assessment that is based on current ideas about early learning and that are consistent with the open framework curriculum. The approaches identified are those

which can be used by educators of children up to the age of six, as appropriate, in a variety of educational contexts.

\section{Characterization of early learning}

Assessment means creating visibility into the various ways children learn (Carr, 2001; Drummond, 1993; Issacs, 1930). It is essential to recognize the unique nature of development in early childhood. During the early period, their children's learning in various dimensions of development the different dimensions of development (for example: physical, motor, linguistic, emotional) is larger than in any other period, but is also very variable throughout them. It happens very quickly, has an episodic character and is very sensitive to environmental conditions (Shepard et al., 1998).

Educators have consistently sought to convey the magnitude and complexity of early processes (Athey, 1990; Bowman et al., 2001; Drummond 1993; Nutbrown, 1999). For example, the complexity of learning is demonstrated by the child's commitment to the act of communication then, through language, in search of meaning and understanding (Trevarthen, 2002; Wells, 1986). This is the genesis of the development of further literacy. The presence of sensitive and empathetic adults who are present and available to children in the early stages of life is a critical factor in facilitating children's learning in the early stages of life.

Evaluation is an ongoing process and involves children's observations in interesting, meaningful, challenging, and valuable experiences (Bowman et al., 2001; Meisels, 1999; Torrance, 2001). Many aspects of early learning are best assessed by observing children as they engage in everyday experiences in an educational setting. Such an approach is considered authentic since the tasks involved are carried out as part of the day-to-day work and are not specifically intended for evaluation. This approach to assessment thus recognizes that curriculum and assessment are intertwined (Puckett \& Black, 2000). 


\section{Theoretical constructs related to early learning}

Recently, a number of perspectives have emerged on the learning process that they have a special resonance for early learning. These include the ecological perspective (Bronfenbrenner, 1979; Bronfenbrenner \& Morris 1998); socio-cultural perspective and the perspective of activity theory (Engestrom et al., 1999). All of these perspectives focus on the social nature of learning and assessment. They also stress the importance the learning environment and the context in which the learning process takes place. There is the number of important constructs that unite them more or less. These include: children as collaborators; children's agency; children as cobuilders of meaning and knowledge. These constructs are especially useful when we think about the quality of interactions between educators and children. Quality interactions are increasingly recognized as central to all aspects of pedagogy, including assessment (Black \& Wiliam, 1998; SirajBlatchford, 2002).

\section{Children's agency}

The agency aims for more control over one's own mental activity (Bruner, 1996). Recognition of the active management of children in participation with adults in social activities is a cornerstone of socio-cultural activity (Rogoff, 1990, 1998). From this perspective, the agency for young children has two dimensions: that related to their efforts to play an active role in the activities of adults and also their efforts to get help from adults when they need it. Rogoff observes how, in social interactions, children manage both their roles and those of adults. She also points out, complementing the work of others, that there is a possibility that they may be more active in situations where there is no deliberate attempt to teach them, ie in "non-false" situations (Rogoff, 1990, 1998). Infants in the first year of life may sometimes be observed to deliberately take the lead in collaborative activities by seeking information or directing activities (Rogoff, 1990, 1998). Children often initiate such activity (Rogoff, 1998). , for example, by trying to help the adult with daily tasks. Older and younger children will seek to assert their independence in doing a special task for 
themselves, but a research by Rogoff suggests that also, will actively seek assistance when they encounter a problem The extent to which children can exercise control is culturally determined (Rogoff, 1990) In some cultures, children are expected not to engage in or engage in adult activities. question, while in other cases children are frequently involved in social activities with adults and are free to make demands in social situations. Of course, the fundamental way in which children declare their control is by determining the direction of their attention.

The context, both interpersonal and socio-cultural, is a key issue not only in terms of what children can learn, but also in terms of the extent to which young children exercise control. The interpersonal dimension is an essential feature of the earliest stages of social interactions and it seems that when very young children engage in communication exchanges with familiar adults, they often rely on mutual imitations. As adults try to engage with children, it has been observed that they respond by imitating certain aspects of their behavior. The child often rewards the adult's attention by expressing joy in different ways. In this way, very young babies act in an "agentive" way, "shaping adult behavior, even if their own behavior is influenced by adults" (Parker-Rees, 2007, p. 9).

Understanding the relationships between young children is also essential for identifying and assessing early learning. For example, young children (aged 14-30 months) have been observed developing communication with other children and varying their imitation of other children's behaviors, thus demonstrating collaboration and control (Lindahl \& Pramling Samuelsson, 2002).

\section{Children, participants in the construction of meaning and knowledge}

In New Zealand, Smith (1999) studied the incidence of joint care episodes between infants and young children and their caregivers in childcare centers. Children, collaborators in the learning process

The theory of learning proposed by Vygotsky (1978) and, in particular, his concept of the area of forthcoming development provides the basis for some of the most important recent initiatives in assessing children's 
individual learning (Lunt, 2000). Berk \& Winsler (1995) describes the area of Vygotsky's next development (ZPD) as:

“...a dynamic area of sensitivity in which learning and cognitive development occur. Tasks that children cannot do individually, but can do with the help of others invoke mental functions that are currently developing, rather than those that are already mature. " (Berk \& Winsler, 1995, p. 26).

Listening-to-child collaboration in the ZPD is essential for effective teaching and learning interactions, because in these interactions the educator identifies how the child's learning can be assisted and what the child is able to do with appropriate support. The educator also has the opportunity to assess the impact of this support on the child's progress. Inter-subjectivity is the place where the adult and the child acquire a common understanding while undertaking a task is approached from different perspectives. The inter-subjectivity obtained by adults and babies is different from that achieved by adults and children who can use linguistic communication (verbal and gestural) to achieve mutual understanding (Rogoff, 1990, 1998). This then has implications for assessment processes in early childhood.

\section{References}

Anning, A., Cullen, J., \& Fleer, M. (2009). Early childhood education: Society and culture. Sage Publications.

Athey, C. (1990). Extending Thought in Young Children: A Parent Teacher Partnership. Paul Chapman Publishing

Berk, L., \& Winsler, A. (1995). Schaffolding Children's Learning: Vygotsky and Early Childhood Education. NAEYC.

Black, P., \& Wiliam, D. (1998). Assessment and Classroom Learning. Assessment in Education: Principles, Policy \& Practice, 5(1), http://dx.doi.org/10.1080/0969595980050102

Blenkin, G. M., \& Kelly, A. V. (Eds.). (1996). Early Childhood Education: A Developmental Curriculum. (2nd ed.). Paul Chapman Educational Publishing.

Bowman, B. T., Donovan, M. S., \& Burns, M. S. (Eds.). (2001). Eager to learn: Educating our preschoolers. National Academy Press.

Bronfenbrenner, U. (1979). Contexts of child rearing: Problems and prospects. American psychologist, 34(10), 844. 
Bronfenbrenner, U., \& Morris, P. A. (1998). The ecology of developmental processes. In W. Damon \& R. M. Lerner (Eds.), Handbook of child psychology: Theoretical models of human development (pp. 993-1028). John Wiley \& Sons Inc.

Bruner, J. (1996). The culture of education. Harvard University Press.

Carr, M. (2001). Assessment in Early Childhood Settings: Learning Stories. SAGE Publications Ltd

Clipa, O. \& Mata, L. (2020). European educational policies on teacher training for early childhood education. In M. Oliinyk, O. Clipa, M. Stawiak-Ososińska (eds.), Trends and prospects of the educational system and educators professional training development (pp. 15-27). Lumen Media Publishing.

Drummond, M. (1993). Assessing Children's Learning. David Fulton Publishers.

Engestrom, Y., Miettinen, R., \& Punamaki, R. L. (1999) Perspectives on Activity Theory. Cambridge University Press. https://doi.org/10.1017/CBO9780511812774

Gipps, C. (1994). Beyond testing: Towards a theory of educational assessment. Falmer Press. Issacs, S. (1930). Intellectual growth in young children. Routledge.

Lindahl, M., \& Pramling Samuelsson, I. (2002). Imitation and Variation: Reflections on toddlers' strategies for learning, Scandinavian Journal of Educational Research, 46(1), 25-45, http://doi.org/10.1080/00313830120115598

Lunt, I. (2000) The practice of assessment. In H. Daniels (Ed.) Educational activity after Vygotsky (pp. 145-170). Routledge.

Meisels, S. J. (1999). Assessing readiness. In Pianta, R. C. \& Cox, M. (Eds.), The transition to kindergarten: Research, policy, training, and practice (pp. 39-66). Paul H. Brookes.

Nutbrown, C. (1999). Threads of Thinking: Young Children Learning and the Role of Early Education. SAGE.

Parker-Rees, R. (2007). Liking to be liked: Imitation, familiarity and pedagogy in the first years of life. Early Years: Journal of International Research \& Development, 27(1), 3-17.

Puckett, M. B., \& Black, J. K. (2000). Authentic assessment of the young child: Celebrating development and learning. Prentice-Hall Order Processing Center

Rogoff, B. (1990). Apprenticeship in thinking: Cognitive development in social context. Oxford University Press.

Rogoff, B. (1998). Cognition as a collaborative process. In W. Damon (Ed.), Handbook of child psychology: Vol. 2. Cognition, perception, and language (pp. 679_ 744). John Wiley \& Sons Inc.

Shepard, L., Kagan, S., \& Wurtz, E. (Eds.). (1998). Principles and recommendations for early childhood assessments. National Education Goals Panel. https://govinfo.library.unt.edu/negp/reports/prinrec.pdf 
Siraj-Blatchford, I. (2009). Conceptualising progression in the pedagogy of play and sustained shared thinking in early childhood education: A Vygotskian perspective. Educational and Child Psychology, 26(2), 77-89.

https://ro.uow.edu.au/sspapers/1224/

Smith, A. (1999). Quality childcare and joint attention. International Journal of Early Years Education, 7(1), 8598.

Torrance, H. (2001). Assessment for learning: Developing formative assessment in the classroom. Education, 29(3), 26-32. https://doi.org/10.1080/03004270185200331

Trevarthen, C. (2002). Learning in companionship: Education in the North. The Journal of Scottish Education, 10, 16-25.

Vygotsky, L. (1978). Mind in society. Harvard University Press.

Wells, G. (1986). The meaning makers. Hodder and Stoughton.

Wood, D. 1998. How children think and learn: The social context of cognitive development. Blackwell. 